\title{
CHRISTIAN RESISTANCE TO GAY-PROSELYTISM IN A SECULAR NIGERIA: ANATHEMA OR SOCIAL HEROISM?
}

\author{
Floribert ENDONG \\ Patrick CALVAIN \\ Department of Theatre and Media Studies, University of Calabar, PMB 1115, CRS, Calabar-Nigeria \\ (C) 2015 Floribert Endong, Patrick Calvain \\ This is an open access article distributed under the Creative Commons Attribution-NonCommercial-NoDerivs license \\ (http://creativecommons.org/licenses/by-nc-nd/3.0/) \\ DOI: $10.1515 /$ eras-2015-0006
}

\begin{abstract}
The criminalization of homosexuality in Nigeria has partially been inspired and acclaimed by a number of religious schools of thought, including Christian opinion leaders. Such an influence of religion on politics has been seriously questioned. Using observations and literary sources, this paper underlines the unconstitutionality of Christian antigay proselytism at the political sphere of the Nigerian State, anchoring its claim on the constitutional provision stipulating the secular character of Nigeria. It however interprets such a move (the "influential" Christian anti-gay proselytism) as an inevitable expression of the religious character of Nigeria's social and cultural spheres. Furthermore, the paper argues that the Nigerian Federation is "fully secular" only on paper and not in practice. Secularity is partially observed at the political sphere of the State. Religion and populism continue to shape major socio-political schemes (as seen in the criminalization of homosexuality in Nigeria). With such a socio-political influence of religion, legislative projects such as the Same-Sex Marriage (Prohibition) Act and political strategies such as the Nigerian Government's resistance against western gay-proselytism can only be massively celebrated. In line with this, (Christian) anti-gay proselytism at the Nigeria's political sphere is logically viewed less as an anathema, and more as socio-political heroism.
\end{abstract}

Keywords: homosexuality, religion, pro/anti-gay proselytism, secularism, same-sex prohibition act

\section{Introduction}

The place of religion in a secular world has variously been perceived by critics and scholars. Some highly fundamentalist religious organizations, religious opinion leaders and scholars have cultivated or supported the tradition of decrying the rapid and "alarming secularization of the most (leading) countries of the world, a secularism which is partly signaled by the legalization of contentious phenomena which run contrarily to core Christian values and are arguably viewed as abominations. Some of these decried anti-Christian values include euthanasia, syndicated motherhood, cloning, abortion, capital punishment, gambling and a wide range of "deviant" sexualities among which must be mentioned homosexuality. The legalization of these traditions (particularly LGBT rights) and more, in most capitalist countries are often so abhorred (by conservatist observers) that some fundamentalist Christian even presumptuously associate them with the "mark of the beast" or with the awful signs of the Armageddon specially announced in the book of Revelation [in the Bible] (Awake, 2015).

It has, in effect, been argued that Christianity (religion in general) has always longed and labored to influence world politics, human civilization and social transformations/revolutions in various subtle ways. Such efforts have, to an extent, been fruitful as such values as humanism, libertarianism and equality among others - forming the bulwark of most western capitalist civilization - partly have their roots in Christianity and other major religions. However, despite the potentials of religion (as a whole) to boost development, most capitalist countries have preferred to adopt the secularist model or paradigm in their nation- 
building efforts. As O'Dea (1966:81) insightfully explains, secularism is seriously antithetical to religion as a system. Secularization discards the traditions which strongly stipulate that a religious worldview is - or should inevitably be - the basic frame of reference for thought. It entails the de-sacralization of attitudes towards persons and things and the rationalization of thought. In O'Dea's words, "[in secularism], there is first the 'desacralization' of the attitude towards persons and things - the withdrawal of the kind of emotional involvement which is to be found in the religious response, in the response to the sacred. Secondly, there is the rationalization of thought - the withholding of emotional participation in thinking about the world".

Secularism also paves the way for subjectivism, liberalism, rationalism, materialism and the like, which are systematically unfriendly to faith, thus to religion. Secularism, in this respect, is viewed as a catalyst of the creation of a common ground which may facilitate the coexistence of both atheist and theist. It enable a conducive environment for the survival of binary opposites notably homosexuals and heterosexuals. However, the prevalence of secularism does not totally or always silence religious fanaticism. As Foret quoted in Trimmer (2014) beautifully puts it, "secularization is not the disappearance of religion, but rather the mutation of religion". Religion is weaker in today's world politics, but it is also far more visible. Indeed, at the political spheres of most developed and developing nations like the USA, Europe and Nigeria among others, religion (particularly Christianity) unofficially remains a cardinal censorial and controlling force. In the USA for instance, the Republican Party - which is recognized as conservatist in nature - has some of its ideals grounded on religious philosophy. Still in the USA, religious lobbies (notably the evangelical Christians under their banner Morality Majority) continue to be strongly felt in the political life of the nation. Their influence is vividly perceived in socio-political revolutions or campaigns. According to Barber (2013), evangelical Christians under the banner of the Moral Majority have been making sustained efforts to influence political leaders since the 1970s and to inject religion into political debates. This broad agenda animates contemporary right-wing media including talk radio personalities such as Rush Limbaugh and TV channels such as Fox News. Barber further underscores the tendency by the two main political denominations to exploit religion for political gains and the religious undertone/coloration of a good number of American political actions.

The religious propensities of immigrants mean that they are receptive to the conservative religious message and can be induced to vote across class lines. In doing so they support a [political] agenda that favors the wealthy and makes them even poorer. Given this threat from the religious right, Democrats feel pressure to emphasize their own religious credentials, or risk losing a chunk of the poorer immigrant population who make up their natural constituency.

So religion is embroiled in American political life and that magnifies the apparent significance of religion in people's everyday lives. According to wits, U.S. conservatives went to war in Afghanistan to separate religion from politics abroad while striving to unite religion and politics at home. American politicians talk a lot about religion. Yet, they have no more in common with theocrats like the Taliban than ordinary Americans have with the religious fervor of ordinary Afghanis. (Barber 2013:34)

The influence of the Christian religion on American politics is also seen in the fact that despite the constitutional firewall between church and state, national politicians hardly ever give a major speech without invoking religion directly or indirectly. The president - for instance - is forever asking God to bless America in his political addresses to the American nation. 
Additionally, he is fond of sending his prayers to victims of disasters, hosting religious leaders, and extolling a variety of religious values.

Similarly to the USA, religious lobbies and political opinion leaders are still influential in a good number of European countries. Though not as strong as in America, religion remains a strong motivational force for political action, notably by EU parliamentarians (Trimmer 2014). A symbiotic relation has been created between religion and politics so much so that, Christianity is virtually not acting independently in places like Europe or North America. Instead, "it forms inseparable part of the regime, of the Empire. Or more precisely, the Empire is fully constructed on Christian doctrines" (Wlcheck 2014). Considering this symbiotic relationship between religion and politics, it has been argued that religion often subtly dictate or inform the positions of politicians and political leaders on certain vital socio-political issues in a good number of both western and African states. A case in point is the demonization, condemnation and criminalization of homosexuality by most African politicians and states, partially on religious, moralist and cultural bases. Such acts (which are visibly informed by religious dogmatism) have often inspired a thorough questioning over the legitimacy of religion - notably Christianity - in the conduct of political affairs in constitutionally secular states. This paper explores this question, using Christian resistance against gay-proselytism in secular Nigeria as a case study.

\section{Theoretical Framework}

This paper hinges on two theories namely the "idealistic" and anomie theories. The first is inspired by the philosophical concept of idealism, a current credited to Plato. Idealism as a philosophical concept generally underscores the priority of ideals, principles, values, and goals over concrete realities. In line with this, idealists are believed to represent the world as it might or should be. Drawing from this premise, the idealist theory in social studies stipulates that the ideals of a certain people or nation will automatically determine their way of life and the organizational structure or patterns of their society. Idealism therefore asserts the independent causal influence of intellectual ideas and values on social organization and culture.

The second theory (anomie) being considered in this paper is related to deviancies occurring as derivates of social revolutions. In Durkheim's usage, anomie analyzes situations in which culture creates a mix of deviance and disunity. In other words, the perspective describes a situation in which cultural norms break down because of rapid social changes or revolutions. However, in Methon's use, anomie theory describes a situation in which there is an apparent lack of compatibility between the culture's norms about what constitutes success in life (goals) and the culture's norms about the appropriate ways to achieve those goals (means). In line with this, the anomie theory - as used in this paper - suggests that social discrimination (in the form of tribalism or religious discrimination) be viewed in relation to prevailing moral values in the society.

\section{The Place of Christianity in a Secular Nigeria}

Determining the place of religion in Nigeria's political architecture in an evidential and clear manner has often proven to be a herculean and delicate task to most critics or political analysts who have given a modicum of attention to the question. Such a herculean task has warranted scholars and critics to mobilize various and sometimes concurrent interpretations of constitutional provisions as well as empirical evidences. However, the question remains worth asking: is Nigeria really a secular, semi-secular or religious state? In other words, what concretely is the place of religion in an intended secular Nigeria? How does the influence of religion on politics fuel Christian anti-gay proselytism in the country? According to Section 10 
of the 1999 Nigerian Constitution, "the Government of the Federation or a State shall not adopt a religion as the State religion". In line with this provision it can be enthused that Nigeria is secular. Section 10 further expresses the constitution drafters' routing for a secular Nigerian Federation, when it makes it clear that

„It may be argued in the light of this provision that religious symbols (indigenous or received) have no place on public lands, national edifices, currency, flag, coat of arms, anthem, pledge and other national symbols. By this section, Nigeria is declared to be a secular state and therefore cannot join any organization that has a religious connotation'.

Through this section, the Nigerian state mainly guarantees freedom of worship and equality of religious faiths which constitute a key milestone of secularism. Additionally Section 10 helps check discrimination based on religion which is equally vital for the formation of a real secular democracy. However, despite this constitutional provision, it has been observed that religion (particularly Islam and Christianity) tremendously shape politics in Nigeria. The country has therefore mainly been secular on paper and glaringly religious in practice as religion remains a clear influencing factor on the political process of the Federation. This is evidenced by Nigerian politicians and political leaders' repeated "flouting" of most of the above mentioned constitutional recommendations. Good illustrations of such a flouting include:

- The allowance of Christian evangelism or Islamic sermons in public,

- The observance of public holidays on Sunday, Saturday, Christmas, New Year, Easter,

- Observance of public holidays on Eid Al-Fitri, Eid AL- Adha and Milad Un Nabi.

- Construction of Chapels and other worship centers even in Government edifices (a good example is former President Olusegun Obandjo's building of a church in Aso Rock),

- Government's subventions on religious pilgrimage (Christian pilgrimage to Jerusalem and Hajj pilgrimage to Mecca),

- the adoption of Islam as a state religion in some Northern State (for instance Zamfara) and application of the sharia law in such states,

- Public oath-taking on the Bible or the Quran,

- Government-sponsored interdenominational religious services,

- Official recognition of some denominations insignia by some Eastern state governments among others

All these political traditions and more are evidences that religion seriously shapes politics in Nigeria. Political leaders have been fond of exploiting religious strategies in their conduct of administrative affairs as well as in their political campaigns. By so doing they have sometimes viciously manipulated religion and malleable religious leaders, for their "selfish" gains. According to Agwu (2015) such a political tactic has been aimed at instigating religious sentiments just to grab power on religious ground. Providing a set of evidences, Agwu further explains that:

„Nigeria is a country where religion can make the most education individual portray the behavior and attitude least expected from the worst illiterate. The incumbent Vice President who is also the Vice Presidential candidate of the People's Democratic Party (PDP) was recently caught on video instigating religious concerns in one of his political campaigns in Kaduna State (another religious volatile state). It is so unfortunate that those who are supposed to engender peaceful co-existence in the country are the very ones causing great disaffection amongst the diverse groups in Nigeria".

In a bid to instigate such religious sentiments, and ensure success in their political campaigns, Nigerian politicians have publicly supported Christians' demonization of homosexuality. Nigerian politician's rigid crusade against homosexuality could therefore 
rightfully be associated to a populist tendency and a smart strategy aimed at winning the sympathy and eventually the votes of the Nigerian masses. According to recent surveys on Nigerians' perception of LGBT people, homosexuality is still very unpopular in the country. A 2014 public opinion poll conducted by a Gallup-affiliated polling firm, indicates that 87 percent of Nigerians support the ban on same sex relationship meanwhile, 8 in 10 believe gay people should not be permitted equal rights (Ugwu 2015). Similar results were obtained by a 2013 survey conducted by NOI Poll which indicated that $92 \%$ of the Nigerian populace support the anti-gay legislation prevailing in the country (TIERS 2014). With such indexes of public opinion, a politician who "dares" manifests pro-homosexuality feelings - especially publicly is, in theory, running the risk of losing his popularity. In line with this, politicians' anti-gay actions could be equated to calculated political ploys ahead of electoral exercises. Such ploys also enable them to tactically divert the attention of masses from thorny socio-economic problems such as poverty, unemployment, inflation, corruption among others.

\section{Christian Anti-Gay Proselytism in a Secular Nigeria: An Anathema?}

As earlier alluded to, Nigeria is a secular state and on this basis, religious sentiments are not expected to drive national policies and laws. Secularism as a political ideology stipulates that religious issues should not be the basis of politics. In the extreme, it holds that religion practically has no place in public life. In other words, the secularist philosophy essentially seeks to preserve the religious neutrality of both government and cultures. Going by this premise, it is safe to argue that official rejection and criminalization of homosexuality is not supposed to be anchored on religious motives/motivations as it is presently the case in Nigeria. It is perhaps due to the inherent weaknesses of the religious argument (in a secular context or dispensation) that Nigerian legislators have preferred to principally use culturalist arguments, stipulating that homosexuality is against core Nigerian cultural values. It is important to note en passant that this cultural argument has been found untenable in some quarters, following a number of recent studies which have aptly demonstrated that homosexuality is not as un-Nigerian as afro-centric politicians have enthused. Such studies have elucidated the presence of homosexual practices in a good number of cultural rituals by Nigerian ethnic groups among which should be mentioned the Igbo, the Hausa, the yan idaudu, just to cite a few (Tamale 2015, Paulat 2015, Zabus 2015). It is equally important here to underscore the fact that, though the culturalist argument is mostly brought to the fore (by anti-gay Nigerian politicians), religious motives/motivations subtly (and in a veiled manner) stand at the root of such political and sociocultural crusade against homosexuality. There is an incontrovertible relationship between religion and politics in Nigeria which is unavoidably reflected in Nigerian politicians' perception and framing of the advocacy and activism for LGBT rights in Nigeria. This symbiosis is, to an extent, visibly detrimental to secularism.

Given the secular character of the state, Christian anti-gay proselytism is supposed to remain exclusively confined to religious circles (where various doctrines against homosexuality do prevail) as well as in other institutions of the socio-cultural sphere (where concervatism is entertained). As Omenga (2014) rightly argued, homosexuality, as far as it is a matter of morality, is not be a "problem" to be tackled by the State; but rather an affair to be handled by the Church (religion). And any failure in curbing it should be considered the failure of religion and not that of the State. Furthermore, under a secular regime, all religious orientations should, in principle, be tolerated, be they theist convictions (often adopted by anti-gay forces) or atheist inclinations (to which LGBT people or activists are often affiliated). This argument is most often mobilized by human right activists who have not hesitated to brand Christian anti-gay proselytism as a grave human right violation. In tandem with this, Omenga (2014) passionately 
contends that:

„The 'Nigerian morality' which abhors same sex union is really its religious expression. The question provoked by this is 'Is religious sentiment, no matter how strong, enough to render an act criminal - and with grave penalty?' The answer would be in the affirmative in a theocratic society; but this is not the case with Nigeria. The Constitution expressly states that Nigeria is a secular state. For this reason, it does not seem wise to use religious sentiments, no matter how pervasive, as a criterion for the criminalization of any act".

The obvious conclusion one may draw from these observations is that Nigeria is "fully secular" on paper and "partially or nominally secular" in reality. Full secularity is somehow a myth in Nigeria as religion continues to tremendously influence politics. It is equally partially based on the prerequisite of secularity of the state (in the strict sense of the notion) that a number of western countries such as USA, Britain, and the European Union have mounted their pressure on Nigeria to decriminalize homosexuality.

The practically "limited" secularity of the Nigerian state creates a situation where in the Christian anti-gay proselytism - exhibited in the political sphere - is seldom seen as an anathema, even though such a phenomenon perfectly deserves to be branded as such, especially if one were to consider the constitutional provisions (guaranteeing secularity and freedom of thought, conscience and religion). A number of civil society organizations (NGOs and human right activists) such as House of Rainbow, The Initiative for Equal Rights (TIERS), International Center for Sexual and Reproductive Rights (INCRESE) and the International Center on Advocacy for Right to Health and Equal Right (WHER) among others are actively working towards demonstrating how unconstitutional and contrary to secular ideals the criminalization of homosexuality is. These civil society organizations particularly stress on the perceived contradiction between the 2010 Same Sex Marriage Prohibition Act (anti-gay laws) and the 1999 Nigerian Constitution. However, the results of their efforts are still so patchy that they seem insignificant to some western or West-based scholars and observers. As at present, anti-gay proselytism in secular Nigeria may not, to most Nigerians, be an anathema. Recent surveys by TERS (2014) and public opinion polls reviewed by Ugwu (2015) somehow suggest such a conclusion.

\section{Christian Anti-gay Proselytism in Nigeria as Social Heroism}

Nigerian moralist and conservatist observers would likely appreciate a constant interaction between religion and politics. This is thanks to the popular belief that religion has the potential to positively contribute to most governmental efforts towards nation building. Though the Nigerian Constitution advocates the secularity of the State, popular beliefs vehemently make a case for the intervention of the religious worldview in conceiving and executing major nation building projects. In point 9 of its Vision 2010 Report, the Nigerian Federation clearly states that: "By the year 2010, it is envisaged that the Nigerian people will rediscover themselves and revert to being God-conscious and God-fearing [...]". In line with this, it is for instance often enthused that the process of good governance may enormously benefit from the truth preached by religion. Additionally, religion could serve as an active agent or tool for positive socio-cultural transformation and political advancement.

It is based on all the above mentioned premises that most religious forces will see their anti-gay actions as a positive socio-cultural campaign. Their efforts in influencing politics particularly with respect to the question of the criminalization of homosexuality may popularly be read as social heroism. The same, politicians' religious sentiments with respect to homosexuality in Nigeria is acclaimed, as demonstrated by recent surveys on the question of homosexuality in Nigeria (TIERS 2014; Ugwu 2015; Ikott 2014). Without wanting to 
undermine the efforts and arguments of the pro-gay activists, it must be underlined that the antigay legislation - at least from a moral point of view - reflects the opinion of most Nigerians on the issue of homosexuality. In other words, despite the fact that they unarguably go against the respect of human rights (the rights of LGBT people) and the ideal of secularity of the State, the laws enjoy a massive support. The Nigerian Government's resistance to western pressure to decriminalize homosexuality is also massively acclaimed. In line with this, Ikott (2014) succinctly notes that:

„For many Nigerians, accustomed to attacking Mr. Jonathan [the former Nigerian President] over his failure to address many of the nation's ills and its stinking corruption, the bill's signing [the signing of the Same-Sex Marriage (Prohibition) Act], largely a popular decision, came as one of the commendable steps taken by his administration. Across the social media and blogosphere, majority of Nigerians heaped praises on a president they are more used to criticizing and pointed out how he has defied international pressure over the bill, and acted in a way deemed to be in Nigeria's interest".

It goes without saying that most Nigerians see in their government's action a culturally and socially beneficial scheme, one which is susceptible to bring a modicum of sanity in the dominantly religious Nigerian society. Pro-gay activism is, in this context, likely to arguably be viewed as an index or a consequence of westernization and deculturalization. The Nigerian mentality is basically the expression of traditional, Christian and Islamic ideals, now subsumed in the 'public policy', the 'modern' legislation and extant customary laws. A contrary philosophical current (gay proselytism) is therefore likely to be associated with cultural and spiritual 'westoxification'.

\section{Conclusion}

Religion still has a profound influence on politics in Nigeria. Such an influence has caused the Nigerian government to proffered religious sentiments in its legislation on homosexuality. It remains clear that with respect to the secularity principle (emphasized by the Nigerian Constitution), Nigeria was supposed to neutralize the religious orientations, in her legislative efforts. The politico-religious base of the Same-Sex Marriage (Prohibition) Actwhich severely criminalizes homosexuality - is mainly viewed as a contradiction of the secularism principle advocated by the Nigerian Constitution. Many members of the civil society organization (particularly LGBT people, pro-gay activist and NGOs) have capitalized on this argument to initiates a number of corrective efforts. However, their initiates have basically yield patchy results which, to an extent, could be viewed as insignificant.

This paper has underlined the unconstitutionality of Christian anti-gay proselytism at the political sphere of the Nigerian State, anchoring its claim on the constitutional provision stipulating the secular character of Nigeria. It however interpreted such a move as an inevitable expression of the religious character of Nigeria's social and cultural spheres. Furthermore, Nigeria is fully secular only on paper. Secularity is partially observed at the political sphere of the State. Religion and populism continue to shape major political scheme (seen in the criminalization of homosexuality). With such a socio-political influence of religion, legislative projects such as the Same-Sex Marriage (Prohibition) Act can only be massively celebrated. In line with this, (Christian) anti-gay proselytism at the Nigeria's political sphere is logically viewed less as an anathema, and more as social heroism. 


\section{References}

Abiodum, Oluwabamide J. (2007). People of Nigeria and Their Cultural Heritage. Lagos: Lisjonhson Resources Publishers.

Adewale, Alfred Martin (2010). Religion and Political Reforms in Nigeria. Sahara Reporters, Available [online] at http://www.religion/and/political/reform/in/nigeria.saharareporters.com Accessed on 31/10/2015.

Agwu, E. E. (2015). The Role of Religion in Politics-Nigeria's Scenario. Nairaland Forum, Available [online] at http://www.the_role_of_religion_in_politics/nairalandfurum.com Accessed on 31/10/2015.

Awake (2015). Is Religion Dying? Awake, New-York: Watchtower Group.

Barber, Niger (2012). Why Atheism Will Replace Religion: The Triumph of Earthly Pleasures Over Pie in the Sky?, New York: Amazon Digital Service.

Barber, Niger (2013). Why Religion Rules American Politics?, New York: Amazon Digital Service.

Ifeanyi M. \& Enwerem, O. P. (2014). A Dangerous Awakening: The Politicization of Religion in Nigeria. Abuja: French Institute for Research in Africa (IFRA)

Ikott, Ini (2014). Anti-Gay Law: Jonathan Draws Praises From Nigerians, Knocks From Abroad, Premium Times, $33,23-30$.

Kehinde, Adegbite (2012). Is Nigeria a Secular or Non-Secular State? Nigerian Muses, 16, 23-45.

O’Dea, T. F. (1966). The Sociology of Religion. New Jersey: Prentice-Hall Inc.

Omenga, Joshua (2014). Anti Homosexual Legislation in Nigeria in Periscope. The Law Students' Blog, Available [online] at http://www.anti-homosexual-legislation-in-nigeria-in-periscope/the-lawstudents-blog.com Acessed on $8 / 11 / 2015$

Sampson, Isaac Terwase (2014). Religion and the Nigerian State: Situating the de Factor and de Jure Frontiers of State-Religion Relations and its Implications for National Security. Oxford Journal of Laws and Religion, 3(2), 311-339.

Tamale, Sylvia (2014). Homosexuality is not Un-African. Al Jazeera Online, Available [online] at http://www.homosexuality_is_not_unafrican_aljazeera_online.htm. Accessed on the 26/09/2015.

TIERs (2014). Survey on Homosexuality Perception in Nigeria, Lagos: The Initiative for Equal Rights.

Trimmer, Michael (2014). Secular Canopy is keeping European Politicians Quiet on Faith. World Magazine, Available [online] at http://www.secular-canopy-is-keeping-european-politicians-quiet-onfaith/worldmagazine.com Accessed on 31/10/2015.

Ugwu, Immanuel (2015). "Nigerians and their Gay Pride". YNaija: The Newspaper for Young Nigerians. Available at http://www.nigerian-and-their-gay-pride/ynaija.com. Accessed on the 14/10/2015.

Witcheck, A. (2014). Christianity, Imperialism, Capitalism: Christian Dogma Should be Questioned. The $4^{\text {th }}$ Media. [online] Available http://www.the4media.christianity_imperialism_capitalism_christian_dogma_should_be_questioned.wit chek.com Accessed on the 15/05/2015.

Zabus, Chantal (2014). Africa has Always Been More Queer than Generally Acknowledged. In Africa is a Country, New York: Routledge. 